\title{
Influence of Fortification of Biscuits with Hyphaene thebaica Flour on Quality Attributes, Biochemical Parameters and Histological Examination of Pancreas in Diabetic Rats
}

\section{Manal M. E. M. Shehata}

Food Sci. Dept. (Rural Home Economics - Food Science and Nutrition), Fac. Agric., Zagazig Univ., Egypt

E-mail: manal.m.e.shehata@gmail.com

\section{Abstract:}

With the widespread use of functional foods, the worldwide looking for new healthy food products with suitable proportions of bioactive ingredients such as fiber, phenolic and flavonoid compounds. Doum is a rich source of fiber and antioxidants. The aim of this research was to use doum flour (DF) in biscuits preparation to increase its nutritional value. Wheat flour was substituted by three levels of DF 10, $20 \& 30 \%$ to prepare biscuits. Chemical and sensory properties of prepared biscuits were studied. Also, the effect of feeding diabetic rats with doum biscuits on biochemical examinations and histological changes of pancreas was assessed. Results showed that increasing the ratio of DF in biscuits led to a significant increase $(\mathrm{P}<0.05)$ in fiber and ash values in prepared biscuits as compared to control. Results recorded that significantly increased gradually $(\mathrm{P}<0.05)$ in phenolic and flavonoid levels as well as antioxidant activity when the level of DF increased in biscuits compared to control. Sensory evaluation showed that biscuits fortified with DF up to $30 \%$ were acceptable by panelists compared to control biscuits. A significant decrease $(\mathrm{P}<0.05)$ in blood glucose, TG, TC, LDL-C and VLDL-C values was noticed after feeding diabetic rats with doum biscuits at different levels of DF, while, insulin and HDL-C levels significantly increased $(\mathrm{P}<0.05)$ comparing with diabetic rats. Findings demonstrated that a significant reduce $(\mathrm{P}<0.05)$ in AST and ALT as well as ALP levels of diabetic rats treated with biscuits containing DF comparing to diabetic rats. Also, kidney functions were significantly improved $(\mathrm{P}<0.05)$ for diabetic rats fed on doum biscuits, whereby both creatinine and urea values in serum were significantly reduced $(\mathrm{P}<0.05)$ compared to diabetic rats. Moreover, feeding diabetic rats with doum biscuits showed marked improvement in pancreatic tissues and these results are consistent with findings obtained above. Results confirmed that the best improvement for all parameters was found in diabetic rats group fed on doum biscuits $(30 \% \mathrm{DF})$ as compared to 
diabetic rats where parameters reached to be near that of the healthy control group. Furthermore, doum biscuits $(30 \% \mathrm{DF})$ have the highest values of fiber and ash as well as phenolic and flavonoid compounds and this associated with the lowest energy value as compared with control biscuits. Accordingly, it can be concluded that doum biscuits which were produced by low cost have potential benefits in the preventing and treating of diabetes and play a role in its management as well as reduce the risk of diabetes complications. Also, doum biscuits could be useful for people suffering from obesity and hyperlipidemia. Thus, this will aid in the promotion of consuming doum biscuits and management problems related to nutrition in Egypt. Therefore, the current study recommends increasing the consumption of bakery products fortified with doum flour, increase consumers awareness about benefits of consuming food products made from doum because its great importance in the preventing and treating of diabetes and some other diseases via the audio-visual media and health centers.

Key words: Hyphaene thebaica, biscuits, fortification, antioxidant activity, alloxan, sensory evaluation and diabetes.

\section{Introduction:}

Diabetes is one of the most common problems challenging the physicians in $21^{\text {st }}$ century (Bennet, 2004). Diabetes mellitus is considered as one of the chronic diseases, it results from the pancreas gland does not produce insufficient insulin or the human body cannot effectively utilize the insulin it produces (WHO, 2006). Diabetes mellitus causes dangerous complications such as kidney failure, stroke, blindness, lower limb amputation and heart attacks (Tripathi and Srivastava, 2006). There has been an increase in the prevalence of diabetes at an alarming rate and this prevalence reached to be epidemic in some of the world's population (Williamson, et al., 2013). Diabetes is one of the biggest health challenges in Egypt, and diabetics in adults (20-79 years) reached to 8.9 million patients in 2019. Egypt is ranked ninth globally in terms of the prevalence of diabetes. It is expected to reach the seventh rank globally by double the number of 16.9 million diabetics by 2045 if it is not well controlled. Middle- and low-income countries has the highest prevalence in diabetes (IDF, 2019).

Diabetes is the third human killer after cancer and cardiovascular diseases, is one of the most challenging diseases facing health care 
professionals today. So, there is a trend to find natural products that lower blood sugar, especially from plant sources.

Hyphaene thebaica is a kind of palm tree which is considered as a member of family Arecaceae and its common name is doum. Doum has been cultivated since ancient times in Egypt as well as found along the Nile River in both Egypt and Sudan where the presence of groundwater. Doum is considered as one of the beneficial plants in worldwide (Fletcher, 1997). Doum fruit is one of nutrients that maintain life in desert areas, specifically during dried periods (Hsu el al., 2006). Doum fruit is rich in minerals including calcium, sodium, potassium, phosphorus and magnesium, moreover, it provides B complex vitamins, carbohydrate and fiber essential for improving human nutrition and health (Aboshora et al., 2014). Also, Hyphaene thebaica a good source of natural antioxidants including tocopherols, vitamin $\mathrm{C}$, carotenoids and phenolic compounds. Hyphaene thebaica is considered as antioxidant (Gharb and Fadhel, 2018), anticancer (Mohammed et al., 2019), antimicrobial (Mohamed et al., 2010), hypotensive (El-Gendy et al., 2008), anti-inflammatory (Farag and Paré, 2013) and hypolipidemic (Elhaj and El-Bagir, 2016). Doum tea is popular in Egypt and is believed to be beneficial for diabetics (Salib et al., 2013). Alcoholic and aqueous extracts of Hyphaene thebaica improved the carbohydrate metabolism of diabetic rats (Abdel-Rahim et al., 2011 and Bayad, 2016). Doum powder was used in some foods as a source of fiber (Aboshora et al., 2019), minerals and stabilizer (Abdelrashid and Hassan, 2005).

The demand for healthy, natural and high-quality products is increasing for Egyptian consumers. So, one of the recent trends is to fortify food products with some nutrients to overcome health problems in particular against diabetes (Abul-Fadl et al., 2016). Biscuits are considered as a common food consumed by a large percentage of the population, due to their long shelf life, varied taste and low cost (Agarawal, 1994).

There is an urgent need to increase the abundance and consumption of healthy foods that appeal to consumers in order to counteract the diet-related diseases such as obesity and diabetes mellitus (type 2). Furthermore, doum is available at a cheap price in Egypt. So, this study aimed to investigate the effect of adding Hyphaene thebaica to biscuits in different concentrations on sensory evaluation, nutritional value, antioxidant content as well as study biological 
effects of feeding diabetic rats on prepared biscuits at various concentrations of doum.

\section{Materials and Methods:}

\section{Materials:}

Hyphaene thebaica (doum) fruit was purchased from local herbal shop in Sharkia Governorate, Egypt. Wheat flour ( $72 \%$ extraction), sugar, salt, shortening, sodium bicarbonate, baking powder and ammonium bicarbonate were obtained from local markets in Sharkia Governorate, Egypt. Casein, cellulose, minerals, vitamins were purchased from El-Gomhoria Company, Sharkia Governorate, Egypt. Purchasing of Folin-Ciocalteu reagent, 2,2diphenyl-1-picrylhydrazyl, gallic acid and alloxan were from Sigma Chemical Company, USA. Kits for blood analysis were purchased from Alkan-Medical Division Biocon, Germany. All chemicals were of the analytical reagent grade.

\section{Methods:}

\section{Preparation of doum flour:}

Doum flour was obtained after grinding the pulp using an electric mill. The milled flour was stored in air-tight polyethylene bags at $4^{\circ} \mathrm{C}$ until used.

\section{Biscuit Preparation:}

Biscuits were prepared by substituting wheat flour (72\% extraction) with 10, 20 and 30\% doum flour (DF) as described by Manohar and Rao, (1999) with modification in amount of sugar which was reduced from 30 to $20 \mathrm{~g} / 100 \mathrm{~g}$ flour. Control sample was prepared without using of doum flour. All the other ingredients were added at the same ratio percentages as follows: wheat flour (100g), shortening (20g), salt (1g), baking powder $(0.3 \mathrm{~g})$, sodium bicarbonate $(0.4 \mathrm{~g})$ and ammonium bicarbonate $(1 \mathrm{~g})$. The basic recipe for biscuits preparation was as follows: sugar and fat were whipped to a white cream for 3-4 min in a mixer. Sodium bicarbonate, ammonium bicarbonate and salt were dissolved in (20-22 $\mathrm{ml}$ water), then the solution was added to the above white cream and mixed for 5 min to obtain a homogenous cream. Wheat flour or mixtures of wheat flour with doum flour were sieved twice with baking powder and were added to the above cream then all were mixed for $3 \mathrm{~min}$. Biscuits dough was sheeted to a thickness of $3.5 \mathrm{~mm}$, sheets were cut using circular shape ( $45 \mathrm{~mm}$ diameter), placed on a tray and baked at $160^{\circ} \mathrm{C}$ for 15 
min, then allowed to cool for $1 \mathrm{hr}$. Biscuits were packaged in polyethylene bags and stored in air-tight containers for further analyses.

\section{Animals preparation:}

Thirty-six adult male wistar strain albino rats weighing between 130 $140 \mathrm{~g}$ were used in this study. Rats were purchased from the Faculty of Veterinary Medicine, Zagazig University, Sharkia Governorate, Egypt. Rats were lived separately in stainless steel cages under hygienic conditions (under standard conditions of temperature, humidity and a light/dark cycle). Animals were allowed to acclimatize for a period of one week before the experiment with free access to food and water ad labium. Rats were fed on a standard diet according to Reeves et al., (1993).

\section{Induction of diabetes:}

Diabetes was induced in overnight fasted rats by single intraperitoneal injections of a freshly prepared solution of alloxan monohydrate $150 \mathrm{mg} / \mathrm{kg}$ BW (Buko et al., 1996) dissolved in physiological saline according to Famakin et al., (2016). Animals were allowed to drink 5\% glucose solution for $24 \mathrm{~h}$ to avoid the drug-induced hypoglycemia. Rats were considered as diabetic, if their blood glucose values were above $250 \mathrm{mg} / \mathrm{dl}$ after three days of alloxan injection (Zheng et al., 2011) and severe diabetic rats were selected for current study.

\section{Experimental design:}

Animals were divided into (6) groups (6 rats for each group). The first group (G1) normal rats serving as normal control, received standard diet and considered as negative control. Diabetic groups (G2), (G3), (G4), (G5) \& (G6) fed as following. The second group (G2) consumed standard diet and considered as positive control. The third group (G3) consumed standard diet after replacement $30 \%$ of the starch in the standard diet by control biscuits. The fourth (G4), fifth (G5) and sixth (G6) groups were fed on the standard diet containing 30\% doum biscuits at different levels 10,20 and 30\%, respectively.

Body weight of rats was recorded at the beginning of the test and then every week and food consumption was recorded daily for twelve weeks. After the end of twelfth weeks of the experiment, rats were anesthetized with diethyl ether after 12 hours fasting. Blood samples were taken via cardiac puncture and centrifuged at $3000 \mathrm{rpm}$ for $20 \mathrm{~min}$ to obtain the serum, which were kept at - 
$20^{\circ} \mathrm{C}$ until analysis. Pancreas was immediately removed from rats to be examined microscopically.

\section{Chemical composition:}

Moisture, protein, ash, fiber and fat were estimated according to AOAC, (2012). Total carbohydrate was calculated by the equation as follows:

Total carbohydrate $=100-($ protein $\%+$ fat $\%+$ ash $\%+$ fiber $\%)$.

\section{Calculation of energy (Kcal/100g sample):}

The energy value (EV) was calculated for different biscuits samples according to Chaney, (2006) as follows:

Energy value $(\mathrm{Kcal} / 100$ sample $)=($ Carbohydrates\% $\% 4)+($ proteins $\%$ x 4$)+$ (fats $\%$ x 9).

\section{Biochemical Analysis:}

Blood glucose estimation was done by using (Trinder, 1969) method. Insulin level was determined by the method of (Temple et al., 1992). Lipid profile [total cholesterol (TC), triglyceride (TG) and high-density lipoprotein cholesterol (HDL-C)] were estimated by using (Richmond, 1973), (Fossati and Prencipe, 1982) and (Burstein et al., 1970) methods, respectively. Lowdensity lipoprotein cholesterol (LDL-C) and very low-density lipoprotein cholesterol (VLDL-C) were calculated by equations as described by (Friedewald et al., 1972). Liver functions [alanine aminotransferase (ALT) and aspartate-aminotransferase (AST)] estimations were carried out by (Reitman and Frankel, 1957), while, alkaline phosphatase (ALP) was estimated as described by Klein and Kaufman, (1967). Kidney functions including urea was determined according to (Patton and Crouch, 1977) method, whereas, creatinine was measured by the method of (Larson, 1972).

\section{Free radical scavenging activity Determination:}

Free radical scavenging activity of raw materials and biscuits was determined using 2,2-diphenyle-1-picrylhydrazyl (DPPH) according to the method described by Brand-Williams et al., (1995).

Total phenolic determination (TP): 
The Folin-Ciocalteu method was used and the measurement was performed at $765 \mathrm{~nm}$ with gallic acid as the standard as described by Singleton et al., (1999). Phenolic values were expressed as mg of gallic acid equivalents (GAE) per g of sample.

\section{Total flavonoid determination (TF):}

Flavonoids was measured at $510 \mathrm{~nm}$ with known quercetin concentration as a standard and expressed as milligrams of quercetin equivalents per g of sample (Zhishen et al., 1999).

\section{Sensory evaluation:}

Organoleptic quality was carried out for biscuits by using 20 semi trained panelists from the staff members of the Department of Food Science, Faculty of Agriculture, Zagazig University, Egypt, to evaluate color, taste, odor, crispness and appearance and overall acceptability (Saleh et al., 2012).

\section{Histological examination:}

After 3 months, rats were euthanized and the pancreas was removed. Samples were washed with normal saline and were fixed in $10 \%$ formalin. The histopathological examination was done as described by Suvarna et al., (2013).

\section{Statistical Analysis:}

Results were analyzed using SPSS program (version 25) and presented as mean \pm standard deviations (SD). The one-way analysis of variance (ANOVA) and Duncan's multiple comparison test were used to determine the most significant effect of feeding by doum biscuits. P-values were considered as significant when $(\mathrm{p}<0.05)$ (IBM SPSS, 2017).

\section{Results and Discussion:}

\section{Chemical composition of doum and wheat flour:}

Chemical characteristics of doum and wheat flour in Table (1), revealed that DF showed higher levels of fiber (14.90\%) and ash $(5.48 \%)$ than wheat flour, conversely, wheat flour indicated higher values of moisture $(11.70 \%)$, protein $(10.05 \%)$, fat $(1.50 \%)$ and carbohydrate $(75.33 \%)$ than DF. Fat content of doum flour was found to be $0.91 \%$ and this result is in agreement with the result reported by Siddeeg et al., (2019). It can be noticed that carbohydrate 
(65.67\%) and protein $(3.63 \%)$ contents of doum flour in the present study were similar to that found by Abubakar et al., (2017) who estimated that carbohydrate and protein levels were 65.90 and 3.34\%, respectively, in doum. Mohammed and Zidan, (2018) reported that moisture and fiber values were 7.81 and $15.50 \%$, respectively, in Egyptian doum. Protein content of wheat flour is close to that determined by Kefale and Yetenayet, (2020) who found that protein reached $10.66 \%$ in wheat flour. These results are in line with Aniess et al., (2015) who found that ash and fat levels in wheat flour were 0.42 and $1.52 \%$, respectively.

Table 1. Chemical composition of doum and wheat flour (as fresh weight).

\begin{tabular}{|l|c|c|}
\hline \multicolumn{1}{|c|}{ Constituents \% } & \multicolumn{2}{|c|}{ Raw materials } \\
\cline { 2 - 3 } & Wheat flour & Doum flour (DF) \\
\hline Moisture & $11.70 \pm 0.52$ & $9.41 \pm 0.30$ \\
\hline Protein & $10.05 \pm 0.65$ & $3.63 \pm 0.20$ \\
\hline Fat & $1.50 \pm 0.12$ & $0.91 \pm 0.02$ \\
\hline Fiber & $1.01 \pm 0.06$ & $14.90 \pm 0.32$ \\
\hline \hline Ash & $0.41 \pm 0.03$ & $5.48 \pm 0.20$ \\
\hline Carbohydrate & $75.33 \pm 1.30$ & $65.67 \pm 1.20$ \\
\hline
\end{tabular}

All values are means of 3 determinations \pm SD.

\section{Phenolic and flavonoid compounds \& DPPH radical scavenging activity of DF:}

From the Table (2) results showed that total phenolic compounds were $32.20 \mathrm{GAE} / \mathrm{g}$ sample in DF, whereas, total flavonoid was $21.40 \mathrm{QE} / \mathrm{g}$ sample. Taha et al., (2020) estimated that flavonoids in doum fruit was $20.40 \mathrm{mg}$ QE/g sample. Atito et al., (2019) stated that total phenolic was $40.65 \mathrm{GAE} / \mathrm{g}$ sample in doum (mesocarp). In addition, DPPH radical scavenging percentage of doum flour was $64.22 \%$. This result is in agreement with Mohamed et al., (2010) who investigated that DPPH scavenging activity was $64.55 \%$ in $H$. thebaica.

Table 2. Phenolic and flavonoid compounds \& DPPH radical scavenging activity of doum flour.

\begin{tabular}{|l|c|c|c|}
\hline Raw material & TP mg GAE/g & TF mg QE/g & DPPH \% \\
\hline Doum flour & $32.20 \pm 0.80$ & $21.40 \pm 0.40$ & $64.22 \pm 1.30$ \\
\hline
\end{tabular}

All values are means of 3 determinations \pm SD. 


\section{Chemical composition for all types of biscuits:}

Moisture, fiber and ash values (as fresh weight) significantly increased $(\mathrm{P}<0.05)$ in made biscuits with increasing the DF level, whereas, protein, carbohydrate, fat and energy values significantly decreased $(\mathrm{P}<0.05)$ comparing with control biscuits (Table 3). Moisture level of biscuits significantly increased $(\mathrm{P}<0.05)$ from $2.71 \%$ in control biscuits to $3.25 \%$ in biscuits fortified with $30 \%$ DF. This result is in line with Aboshora et al., (2016) who found that fortified bread with doum flour led to a significant increase in moisture level. The gradual increase in moisture content probably is due to the increase in water retention ability of fibers, also, increase the amount of water required to make the dough of biscuits which have more level of fiber (Choudhury et al., 2015). Results indicated that protein and fat values of biscuits decreased from 7.63 to $6.48 \%$ and from 14.53 to $14.20 \%$, respectively, with increasing of the amount of DF perhaps this is due to low values of protein $(3.63 \%)$ and fat $(0.91 \%)$ in DF as compared with wheat flour. Similar result was found by Aboshora et al., (2016) who stated that doum flour-wheat flour bread contained less protein than the control bread. Furthermore, current findings showed that fiber content in control biscuits $(0.77 \%)$ was the lowest as compared with other prepared biscuits with different proportions of DF. The amount of fiber in doum biscuits with various concentrations of DF $(10,20$ and $30 \%)$ was $2.17,3.67$ and $5.22 \%$, respectively. Results indicated that fiber content in doum biscuits $(30 \% \mathrm{DF})$ was approximately sevenfold that of the control biscuits. These results perhaps are due to DF has higher amount of fiber (14.9\%) than wheat flour $(1.01 \%)$. The amount of ash in control biscuits was reported to be $0.36 \%$, while, ash level was significantly increased $(\mathrm{P}<0.05)$ in doum biscuits prepared with different concentrations of DF (10-30\%) from 0.96 to $2.00 \%$. Findings revealed that ash level in biscuits containing $30 \%$ DF was approximately sixfold that of the control biscuits. This increase in ash value of doum biscuits perhaps is attributed to higher ash content in DF $(5.48 \%)$ than wheat flour $(0.41 \%)$. Biscuits fortified with $30 \%$ doum flour had the lowest carbohydrate (68.85\%) and energy (429.12\%) values as compared with control biscuits. The same findings were found for moisture, protein, fiber, ash and carbohydrate in doum toast bread by El-Hadidy and El-Dreny, (2020) and for fat in doum bread by Aboshora et al., (2016).

TP and TF \& antioxidant activity of biscuits samples are also clarified in

Table (3). Replacement of wheat flour with DF had caused significantly 
increased $(\mathrm{P}<0.05)$ in phenolics content as compared to control biscuits. Phenolic values in biscuits samples were gradually increased with increasing doum flour level in biscuits. The highest total phenolic was found in biscuits fortified with $30 \% \mathrm{DF}(9.10 \mathrm{mg} \mathrm{GAE} / \mathrm{g})$ and the increasing was approximately 8 -times in comparison to control biscuits $(1.10 \mathrm{mg} \mathrm{GAE} / \mathrm{g})$. These results perhaps are due to DF has higher amount of TP than wheat flour.

In comparison with control biscuits, flavonoid levels among biscuits fortified with $10-30 \%$ DF were significantly increased $(\mathrm{P}<0.05)$. The maximum value of TF was noticed in biscuits containing 30\% DF $(5.31 \mathrm{mg} \mathrm{QE} / \mathrm{g}$ ) compared with control biscuits $(0.21 \mathrm{mg} \mathrm{QE} / \mathrm{g})$ or other biscuits samples. TF increased in doum biscuits (30\% DF) about 25-times in comparison to control biscuits. These findings probably are due to higher level of TF in DF than wheat flour.

With increasing DF content in biscuits DPPH radical scavenging percentage significantly increased $(\mathrm{P}<0.05)$ as compared to control biscuits. DPPH radical scavenging percentage for doum biscuits fortified with 10, 20 and $30 \%$ DF was $26.70,32.70$ and $38.10 \%$, respectively, while, for control biscuits the percentage was $21.20 \%$. The antioxidant activity of doum biscuits $(30 \%$ DF) was $79.7 \%$ higher than control biscuits. The increase in free radical scavenging percentage in doum biscuits perhaps is due to increase in the proportion of phenolic content in DF than wheat flour (Abou-Elalla, 2009). Seleem, (2015) obtained that an increase in the amount of total phenolic and antioxidant activity by adding doum flour to cakes.

Table 3. Chemical composition for all types of biscuits.

\begin{tabular}{|l|c|c|c|c|}
\hline \multirow{2}{*}{\multicolumn{1}{|c|}{ Parameters }} & \multicolumn{3}{c|}{ Samples } \\
\cline { 2 - 3 } \multicolumn{1}{|c|}{} & Control & $\mathbf{1 0 \%}$ DF & $\mathbf{2 0 \%}$ DF & 30\% DF \\
\hline Moisture\% & $2.71 \pm 0.10^{\mathrm{c}}$ & $2.89 \pm 0.15^{\mathrm{b}}$ & $3.09 \pm 0.03^{\mathrm{a}}$ & $3.25 \pm 0.03^{\mathrm{a}}$ \\
\hline \hline Protein \% & $7.63 \pm 0.16^{\mathrm{a}}$ & $7.18 \pm 0.12^{\mathrm{b}}$ & $6.79 \pm 0.15^{\mathrm{c}}$ & $6.48 \pm 0.11^{\mathrm{d}}$ \\
\hline Fat\% & $14.53 \pm 0.22^{\mathrm{a}}$ & $14.38 \pm 0.31^{\mathrm{ab}}$ & $14.28 \pm 0.23^{\mathrm{c}}$ & $14.20 \pm 0.32^{\mathrm{d}}$ \\
\hline Fiber\% & $0.77 \pm 0.02^{\mathrm{d}}$ & $2.17 \pm 0.03^{\mathrm{c}}$ & $3.67 \pm 0.04^{\mathrm{b}}$ & $5.22 \pm 0.04^{\mathrm{a}}$ \\
\hline Ash\% & $0.36 \pm 0.01^{\mathrm{d}}$ & $0.96 \pm 0.02^{\mathrm{c}}$ & $1.51 \pm 0.02^{\mathrm{b}}$ & $2.00 \pm 0.02^{\mathrm{a}}$ \\
\hline Carbohydrate\% & $74.00 \pm 1.35^{\mathrm{a}}$ & $72.42 \pm 1.33^{\mathrm{b}}$ & $70.66 \pm 1.20^{\mathrm{c}}$ & $68.85 \pm 1.11^{\mathrm{d}}$ \\
\hline EV Kcal/100g & $457.29 \pm 2.32^{\mathrm{a}}$ & $447.82 \pm 2.40^{\mathrm{b}}$ & $438.32 \pm 2.50^{\mathrm{c}}$ & $429.12 \pm 2.35^{\mathrm{d}}$ \\
\hline DPPH \% & $21.20 \pm 1.00^{\mathrm{d}}$ & $26.70 \pm 1.12^{\mathrm{c}}$ & $32.70 \pm 1.00^{\mathrm{b}}$ & $38.10 \pm 1.20^{\mathrm{a}}$ \\
\hline TP mg GAE/g & $1.10 \pm 0.05^{\mathrm{d}}$ & $3.80 \pm 0.14^{\mathrm{c}}$ & $6.30 \pm 0.15^{\mathrm{b}}$ & $9.10 \pm 0.13^{\mathrm{a}}$ \\
\hline TF mg QE/g & $0.21 \pm 0.01^{\mathrm{d}}$ & $1.71 \pm 0.11^{\mathrm{c}}$ & $3.41 \pm 0.10^{\mathrm{b}}$ & $5.31 \pm 0.10^{\mathrm{a}}$ \\
\hline \hline
\end{tabular}

Values within the same line followed by various superscripts are significantly different at $(p<0.05)$. 


\section{Sensory evaluation for all types of biscuits:}

Sensory evaluation results for all types of prepared biscuits are illustrated in Table (4). Findings indicated that odor, taste and overall acceptability scores significantly increased $(\mathrm{P}<0.05)$ with increasing the percentage of DF in biscuits compared to control biscuits. Addition of DF to biscuits led to improve odor and taste of biscuits this is perhaps is due to the good flavor of doum. Similar observations were reported by El-Hadidy and ElDreny, (2020) who stated that taste and odor scores significantly increased with increasing doum powder in toast bread. Results demonstrated that no significant differences $(\mathrm{P}<0.05)$ were observed between biscuits fortified with various levels of DF (10, 20 and 30\%) and the control biscuits in color, crispness and appearance. Biscuits fortified with $30 \%$ DF recorded the highest scores for all sensory properties.

Table 4. Sensory evaluation of prepared biscuits with various levels of DF.

\begin{tabular}{|c|c|c|c|c|c|c|}
\hline Samples & $\begin{array}{c}\text { Color } \\
(\mathbf{1 0 )}\end{array}$ & $\begin{array}{c}\text { Taste } \\
\mathbf{( 1 0 )}\end{array}$ & $\begin{array}{c}\text { Odor } \\
\mathbf{( 1 0 )}\end{array}$ & $\begin{array}{c}\text { Crispness } \\
\mathbf{( 1 0 )}\end{array}$ & $\begin{array}{c}\text { Appearance } \\
(\mathbf{1 0 )}\end{array}$ & $\begin{array}{c}\text { Overall } \\
\text { Acceptability (10) }\end{array}$ \\
\hline Control & $9.10 \pm 0.22^{\mathrm{a}}$ & $7.80 \pm 0.23^{\mathrm{d}}$ & $7.50 \pm 0.22^{\mathrm{d}}$ & $8.71 \pm 0.20^{\mathrm{a}}$ & $9.23 \pm 0.31^{\mathrm{a}}$ & $8.70 \pm 0.26^{\mathrm{c}}$ \\
\hline $\mathbf{1 0 \% \text { DF }}$ & $9.15 \pm 0.21^{\mathrm{a}}$ & $8.20 \pm 0.26^{\mathrm{c}}$ & $8.00 \pm 0.24^{\mathrm{c}}$ & $8.79 \pm 0.22^{\mathrm{a}}$ & $9.26 \pm 0.32^{\mathrm{a}}$ & $9.00 \pm 0.25^{\mathrm{b}}$ \\
\hline $\mathbf{2 0 \% \text { DF }}$ & $9.20 \pm 0.31^{\mathrm{a}}$ & $8.70 \pm 0.35^{\mathrm{b}}$ & $8.60 \pm 0.31^{\mathrm{b}}$ & $8.88 \pm 0.27^{\mathrm{a}}$ & $9.30 \pm 0.34^{\mathrm{a}}$ & $9.20 \pm 0.24^{\mathrm{a}}$ \\
\hline $\mathbf{3 0 \%} \mathbf{D F}$ & $9.32 \pm 0.36^{\mathrm{a}}$ & $9.20 \pm 0.33^{\mathrm{a}}$ & $9.30 \pm 0.33^{\mathrm{a}}$ & $8.90 \pm 0.31^{\mathrm{a}}$ & $9.42 \pm 0.41^{\mathrm{a}}$ & $9.36 \pm 0.30^{\mathrm{a}}$ \\
\hline
\end{tabular}

Values within the same column followed by various superscripts are significantly different at $(\mathbf{p}<\mathbf{0 . 0 5 )}$.

\section{Effect of feeding diabetic rats with doum biscuits on BWG, FI and FER:}

As shown\#\#\#\#Table (5), results indicated that\#significantly decreased $(\mathrm{P}<0.05)$ in $\mathrm{BWG}, \mathrm{FI}$ and FER of diabetic rats $(\mathrm{G} 2)$ compared to normal control rats (G1) and these results are in agreement with results obtained by Alsuhaibani and Al-Kuraieef, (2018). Current results revealed that significantly increased $(\mathrm{P}<0.05)$ in food intake among diabetic rats consumed doum biscuits comparing with diabetic rats or diabetic rats fed on control biscuits. Also, results indicated that a significant improve $(\mathrm{P}<0.05)$ in $\mathrm{BWG}$ and FER of diabetic rats consumed doum biscuits as compared with diabetic rats or diabetic rats fed on control biscuits. Findings found that although the food intake in diabetic rats consumed doum biscuits at different levels increased more than normal control group but the body weight gain didn't increase more than control group. These results perhaps are due to DF has higher fiber content 
$(14.9 \%)$ than wheat flour (1.01\%). The best improvement was found in diabetic rats consumed doum biscuits $(30 \% \mathrm{DF})$.

Table 5: Effect of feeding with doum biscuits on (BWG), (FI) and (FER) of diabetic rats.

\begin{tabular}{|c|c|c|c|c|}
\hline Groups & $\begin{array}{c}\text { Body weight gain } \\
\text { (BWG) }(\mathbf{g})\end{array}$ & $\begin{array}{c}\text { Body weight gain } \\
\text { (BWG) }(\mathbf{\%})\end{array}$ & $\begin{array}{c}\text { Food intake (FI) } \\
\text { (g/rat/3months) }\end{array}$ & $\begin{array}{c}\text { Feed efficiency } \\
\text { ratio (FER) }\end{array}$ \\
\hline G1 & $110.70 \pm 1.10^{\mathrm{a}}$ & $85.15 \pm 0.60^{\mathrm{a}}$ & $1620 \pm 2.30^{\mathrm{c}}$ & $0.068 \pm 0.003^{\mathrm{a}}$ \\
\hline G2 & $60.20 \pm 0.50^{\mathrm{f}}$ & $44.93 \pm 0.50^{\mathrm{f}}$ & $1458 \pm 2.20^{\mathrm{e}}$ & $0.041 \pm 0.001^{\mathrm{c}}$ \\
\hline G3 & $65.00 \pm 0.81^{\mathrm{e}}$ & $48.15 \pm 0.22^{\mathrm{e}}$ & $1530 \pm 2.10^{\mathrm{d}}$ & $0.042 \pm 0.001^{\mathrm{c}}$ \\
\hline G4 & $73.30 \pm 0.67^{\mathrm{d}}$ & $53.12 \pm 0.23^{\mathrm{d}}$ & $1629 \pm 2.30^{\mathrm{c}}$ & $0.045 \pm 0.001^{\mathrm{bc}}$ \\
\hline G5 & $83.70 \pm 0.60^{\mathrm{c}}$ & $59.86 \pm 0.30^{\mathrm{c}}$ & $1665 \pm 2.40^{\mathrm{b}}$ & $0.050 \pm 0.002^{\mathrm{b}}$ \\
\hline G6 & $86.20 \pm 0.80^{\mathrm{b}}$ & $64.81 \pm 0.32^{\mathrm{b}}$ & $1692 \pm 2.30^{\mathrm{a}}$ & $0.051 \pm 0.001^{\mathrm{b}}$ \\
\hline
\end{tabular}

Values within the same column followed by various superscripts are significantly different at $(\mathbf{p}<\mathbf{0 . 0 5})$.

\section{Effect of feeding diabetic rats with doum biscuits on glucose and insulin values:}

As presented in Table (6), results obtained from the present study showed that significantly increased $(\mathrm{P}<0.05)$ in glucose level as well as this was associated with decrease in insulin value of diabetic rats as compared to healthy rats and these results are in agreement with the observation reported by Helal $\boldsymbol{e t}$ al., (2014). Diabetic rats consumed doum biscuits revealed that a significant decrease $(\mathrm{P}<0.05)$ in blood glucose values, while, there was significantly increased $(\mathrm{P}<0.05)$ in insulin values comparing with diabetic rats or diabetic rats consumed control biscuits and this improvement increased with increasing the level of DF in biscuits. Similar results were reported by Abdel-moniem et al., (2015) who stated that Hyphaene thebaica extract significantly reduced blood glucose values in diabetic rats. These results perhaps are due to DF has higher level of flavonoid compounds comparing with wheat flour. The best values of glucose and insulin were in diabetic rats treated with biscuits prepared with $30 \%$ DF where glucose value was reduced by $54 \%$, whereas, the value of insulin increased by $32.7 \%$ compared to diabetic rats. In the best treatment glucose and insulin levels reached to be near that of the healthy control group. 
Table 6: Effect of feeding with doum biscuits on glucose and insulin values of diabetic rats.

\begin{tabular}{|c|c|c|}
\hline Groups & Glucose $\mathbf{~ m g / d l}$ & Insulin $\boldsymbol{\mu I U} / \mathbf{m l}$ \\
\hline G1 & $117.00 \pm 1.00^{\mathrm{e}}$ & $4.25 \pm 0.11^{\mathrm{a}}$ \\
\hline G2 & $260.50 \pm 2.11^{\mathrm{a}}$ & $2.60 \pm 0.02^{\mathrm{e}}$ \\
\hline G3 & $259.30 \pm 2.10^{\mathrm{a}}$ & $2.63 \pm 0.04^{\mathrm{e}}$ \\
\hline G4 & $208.00 \pm 1.13^{\mathrm{b}}$ & $2.90 \pm 0.03^{\mathrm{d}}$ \\
\hline G5 & $161.70 \pm 1.12^{\mathrm{c}}$ & $3.15 \pm 0.03^{\mathrm{c}}$ \\
\hline G6 & $120.00 \pm 1.10^{\mathrm{d}}$ & $3.45 \pm 0.04^{\mathrm{b}}$ \\
\hline
\end{tabular}

Values within the same column followed by various superscripts are significantly different at $(\mathrm{p}<0.05)$.

\section{Effect of feeding diabetic rats with doum biscuits on lipid profile:}

Lipid profile for diabetic rats fed on biscuits fortified with DF are clarified in Table (7). Values of TG, TC, LDL-C and VLDL-C were significantly higher $(\mathrm{P}<0.05)$ in diabetic rats than normal control group. Level of HDL-C in positive control group was significantly lower $(\mathrm{P}<0.05)$ than negative control group. While, diabetic rats consumed biscuits containing DF demonstrated that a significant improve $(\mathrm{P}<0.05)$ in all lipid's parameters compared to positive control group or diabetic rats consumed control biscuits and this improvement increased with increasing the level of DF in biscuits. These results perhaps are due to that DF has higher fiber and flavonoids than wheat flour. Current study found that diabetic rats fed on biscuits fortified with $30 \%$ DF recorded the best result for all measurements of lipid profile and values of parameters reached to nearly normal values. In the best treatment levels of TG, TC, LDL-C and VLDL-C decreased by 52.8, 47.6, 68.6 and 52.8\%, respectively, and values of HDL-C increased by $60.1 \%$ compared to diabetic rats. Similar results were obtained by Abdulazeez et al., (2019) who found that treatment of obese rats with flavonoid-rich fraction of $H$. thebaica led to a significant decrease in TC, TG and LDL-C, while, the levels of HDL-C significantly increased.

Table 7: Effect of feeding with doum biscuits on lipid profile of diabetic rats.

\begin{tabular}{|c|c|c|c|c|c|c|}
\hline Groups & TG (mg/d) & TC (mg/dl) & HDL-C (mg/dl) & LDL-C (mg/dl) & VLDL-C (mg/dl) \\
\hline G1 & $73.30 \pm 1.00^{\mathrm{e}}$ & $108.50 \pm 1.10^{\mathrm{e}}$ & $49.90 \pm 0.40^{\mathrm{a}}$ & $43.94 \pm 0.50^{\mathrm{f}}$ & $14.66 \pm 0.32^{\mathrm{d}}$ \\
\hline G2 & $160.00 \pm 2.12^{\mathrm{a}}$ & $210.00 \pm 2.10^{\mathrm{a}}$ & $30.30 \pm 0.30^{\mathrm{e}}$ & $147.70 \pm 1.30^{\mathrm{a}}$ & $32.00 \pm 0.40^{\mathrm{a}}$ \\
\hline G3 & $159.00 \pm 2.21^{\mathrm{a}}$ & $209.30 \pm 2.20^{\mathrm{a}}$ & $31.00 \pm 0.20^{\mathrm{e}}$ & $146.50 \pm 1.12^{\mathrm{b}}$ & $31.80 \pm 0.32^{\mathrm{a}}$ \\
\hline G4 & $131.84 \pm 1.22^{\mathrm{b}}$ & $176.82 \pm 1.24^{\mathrm{b}}$ & $36.40 \pm 0.20^{\mathrm{d}}$ & $114.05 \pm 1.11^{\mathrm{c}}$ & $26.37 \pm 0.26^{\mathrm{b}}$ \\
\hline G5 & $104.28 \pm 1.13^{\mathrm{c}}$ & $142.80 \pm 1.13^{\mathrm{c}}$ & $42.72 \pm 0.30^{\mathrm{c}}$ & $79.22 \pm 1.10^{\mathrm{d}}$ & $20.86 \pm 0.21^{\mathrm{c}}$ \\
\hline G6 & $75.52 \pm 1.00^{\mathrm{d}}$ & $110.04 \pm 1.10^{\mathrm{d}}$ & $48.50 \pm 0.22^{\mathrm{b}}$ & $46.44 \pm 0.60^{\mathrm{e}}$ & $15.10 \pm 0.20^{\mathrm{d}}$ \\
\hline
\end{tabular}

Values within the same column followed by various superscripts are significantly different at $(\mathbf{p}<0.05)$. 


\section{Effect of feeding diabetic rats with doum biscuits on liver and kidney function parameters:}

Kidney and liver function assessments for healthy control rats, diabetic rats and diabetic rats consumed biscuits fortified with different levels of DF are showed in Table (8). Levels of alanine and aspartate aminotransferase (ALT and AST) as well as alkaline phosphatase (ALP) were significantly increased $(\mathrm{P}<0.05)$ in diabetic rats $(\mathrm{G} 2)$ comparing with healthy control group (G1). Similar findings reported by Tohamy et al., (2013b). Findings indicated that no significant change recorded $(\mathrm{P}<0.05)$ in alanine and aspartate aminotransferase (ALT and AST) as well as alkaline phosphatase (ALP) among diabetic rats consumed control biscuits as compared to diabetic rats. Data showed that significantly decreased $(\mathrm{P}<0.05)$ in values of alanine and aspartate aminotransferase (ALT and AST) as well as alkaline phosphatase (ALP) of diabetic rats consumed biscuits fortified with DF with increasing the doum flour level in biscuits as compared to diabetic rats. These results perhaps are due to DF has higher amount of phenolic and flavonoid compounds than wheat flour. The best improvement for liver functions found in diabetic rats fed on biscuits fortified with $30 \%$ DF where serum values of alanine and aspartate aminotransferase (ALT and AST) \& alkaline phosphatase (ALP) were significantly decreased $(\mathrm{P}<0.05)$ from 40.30 to $26.15(\mathrm{U} / \mathrm{L}), 60.0$ to $45.0(\mathrm{U} / \mathrm{L})$ and 110.0 to $87.0(\mathrm{U} / \mathrm{L})$, respectively. Current findings are in line with the observation of Salib et al., (2013) who demonstrated that there was improved in liver parameters of rats with diabetes treated with flavonoid compounds from Hyphaene thebaica.

Urea and creatinine are parameters used to evaluate kidney functions. In the present study, both urea and creatinine values were significantly increased $(\mathrm{P}<0.05)$ in diabetic rats comparison with control rats and these results are in agreement with findings obtained by Abdel-moniem et al., (2015). Furthermore, results revealed that urea and creatinine were significantly decreased $(\mathrm{P}<0.05)$ in diabetic rats feeding with biscuits containing DF at different levels as compared to diabetic rats or diabetic rats consumed control biscuits. This improvement in kidney functions increased with increasing the level of DF in biscuits. These findings are attributed to DF has higher flavonoids content than wheat flour. The highest improve in kidney functions was found in diabetic rats treated with biscuits fortified with $30 \%$ DF where values of creatinine and urea decreased from 1.70 to $0.94(\mathrm{mg} / \mathrm{dl})$ and 60.80 to $46.30(\mathrm{mg} / \mathrm{dl})$, respectively. Shehata and Abd El-Ghffar, (2017) stated that 
administration of $H$. thebaica extract led to a significant improve in creatinine and urea in mercuric chloride treated animals.

Table 8: Effect of feeding with doum biscuits on kidney and liver functions of diabetic rats.

\begin{tabular}{|c|c|c|c|c|c|}
\hline \multirow[t]{2}{*}{ Groups } & \multicolumn{3}{|c|}{ Liver functions (U/L) } & \multicolumn{2}{|c|}{ Kidney functions (mg/dl) } \\
\hline & ALT & AST & ALP & Urea & Creatinine \\
\hline G1 & $25.20 \pm \cdot .30^{\mathrm{e}}$ & $36.40 \pm 0.40^{\mathrm{e}}$ & $84.00 \pm 1.10^{\mathrm{e}}$ & $39.80 \pm 1 . \cdot 0^{\mathrm{e}}$ & $\cdot .86 \pm 0 . \cdot 2^{\mathrm{d}}$ \\
\hline G2 & $40.30 \pm 0.50^{\mathrm{a}}$ & $60.00 \pm 0.5^{{ }^{a}}$ & $110.00 \pm 1.30^{\mathrm{a}}$ & $60.80 \pm 1.10^{\mathrm{a}}$ & $1.70 \pm 0 . \cdot r^{\mathrm{a}}$ \\
\hline G3 & $40.00 \pm 0.32^{\mathrm{a}}$ & $59.40 \pm 0.3^{{ }^{\mathrm{a}}}$ & $109.10 \pm 1.20^{\mathrm{a}}$ & $60.00 \pm 1.1^{{ }^{\mathrm{a}}}$ & $1.68 \pm 0.2^{\mathrm{a}}$ \\
\hline G4 & $35.58 \pm 0.24^{b}$ & $55.00 \pm 0.22^{\mathrm{b}}$ & $102.30 \pm 1.20^{b}$ & $55.90 \pm 1.) 1^{\mathrm{b}}$ & $1.44 \pm 0 . r^{\mathrm{b}}$ \\
\hline G5 & $31.20 \pm 0.13^{\mathrm{c}}$ & $50.40 \pm 0.20^{\mathrm{c}}$ & $94.00 \pm 1.30^{\mathrm{c}}$ & $51.40 \pm 1.10^{\mathrm{c}}$ & $1.21 \pm 0 . \cdot^{\mathrm{c}}$ \\
\hline G6 & $26.15 \pm 0.20^{\mathrm{d}}$ & $45.00 \pm 0.35^{\mathrm{d}}$ & $87.00 \pm 1.22^{\mathrm{d}}$ & $46.30 \pm 1.00^{\mathrm{d}}$ & $\cdot .94 \pm 0 . \cdot^{\mathrm{d}}$ \\
\hline
\end{tabular}

Values within the same column followed by various superscripts are significantly different at $(\mathbf{p}<\mathbf{0 . 0 5})$.

\section{Histological examination:}

Histological examination of the healthy rat's pancreas showed normal islets cells with prominent beta and alpha cells beside normal pancreatic acini (Photo. 1). While, diabetic rat's pancreas displayed focal apoptotic and necrotic change of islets. In addition, reduction in the islet cellular density and a severe decrease in the number of cells in the islets. Moreover, congested pancreatic blood vessels were also seen (Photo. 2). These findings are in accordance with results reported by Mohamed et al., (2019). Pancreas of diabetic rats fed on control biscuits showed congested pancreatic blood vessels. Some of the islets cells showed reduction of cellular population which represented by some apoptotic and necrotic islets cells. Furthermore, some inflammatory cells were infiltrated periductal and perivascular (Photo. 3). Pancreas of diabetic rats fed on biscuits fortified with $10 \%$ DF revealed some normal islets of Langerhans and pancreatic acini. In addition, few apoptotic islets cells were also detected (Photo. 4). Most of pancreatic islets of diabetic rats fed on biscuits fortified with 20\% DF restore their sizes, number and cell population. Moreover, normal exocrine parts were also observed (Photo. 5). Majority of pancreatic islets of diabetic rats consumed doum biscuits $(30 \% \mathrm{DF})$ were large in size or normal sizes with apparently normal active cellular contents. Moreover, the exocrine pancreas displayed clearly normal pancreatic acini (Photo. 6). These findings probably are due to doum has antioxidant activity causes increase the number of $\beta$-cells by increasing the repair and regeneration of $\beta$-cells and protect cell membranes from oxidative damage. Tohamy et al., (2013a) reported that 


\section{diabetic rats fed on Hyphaene thebaica suspensions displayed normal} pancreatic tissues.

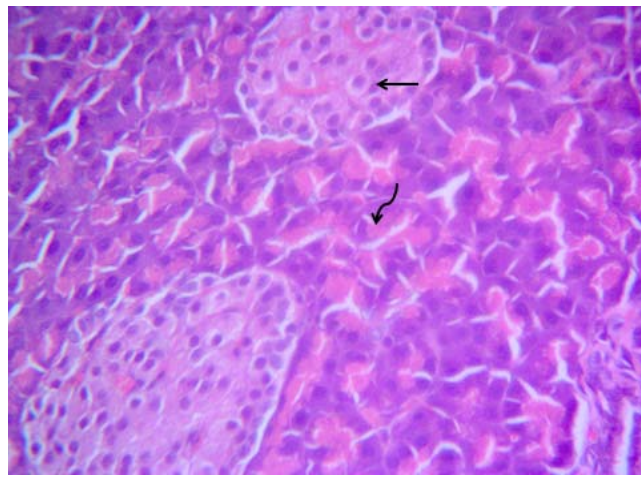

Photo. 1 (G1): Photomicrograph of pancreas showing normal islets cells (arrow) and pancreatic acini (curved arrow). H\&E X400.

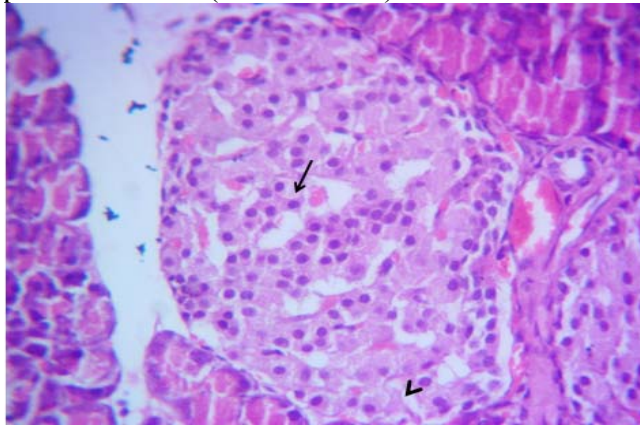

Photo. 3 (G3): Photomicrograph of pancreas showing some apoptotic (arrow) and necrotic islets cells (arrow head). H\&E X400.

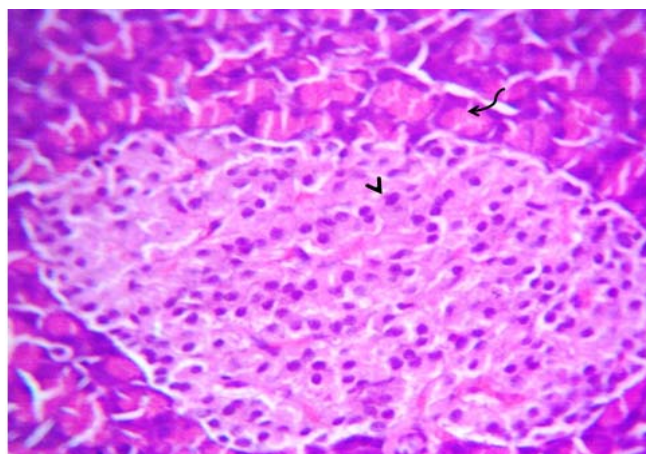

Photo. 5 (G5): Photomicrograph of pancreas showing clearly active cellular contents of pancreatic islets cells (arrow head) and normal pancreatic acini (curved arrow). H\&E X400.

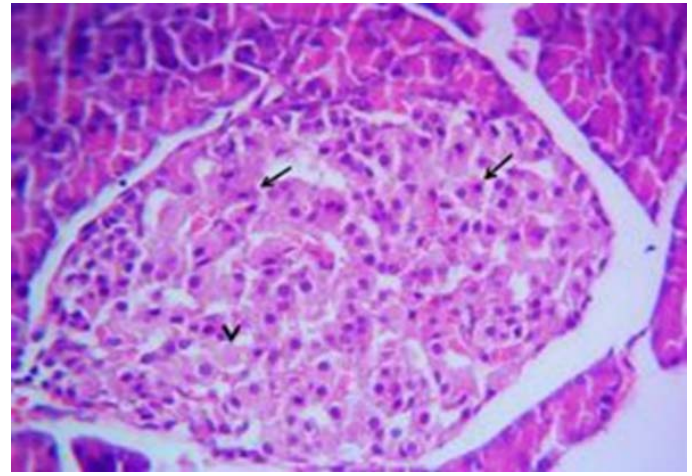

Photo. 2 (G2): Photomicrograph of pancreas showing apoptotic (arrows) and necrotic change (arrow head) of islets. H\&E X400.

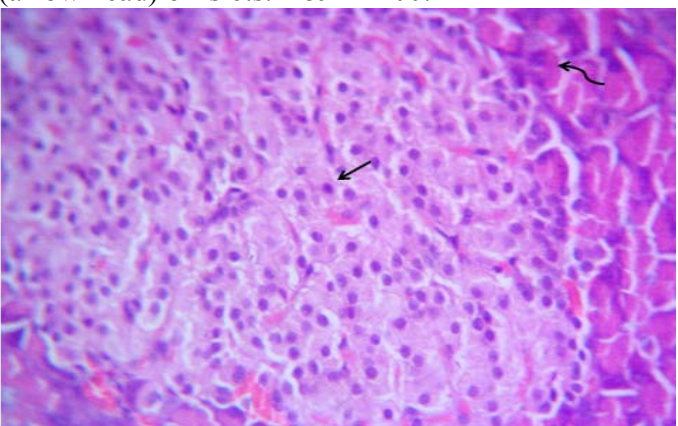

Photo. 4 (G4): Photomicrograph of pancreas showing apparently normal pancreatic acini (curved arrow) with few apoptotic islets cells (arrow). H\&E $\mathrm{X} 400$.

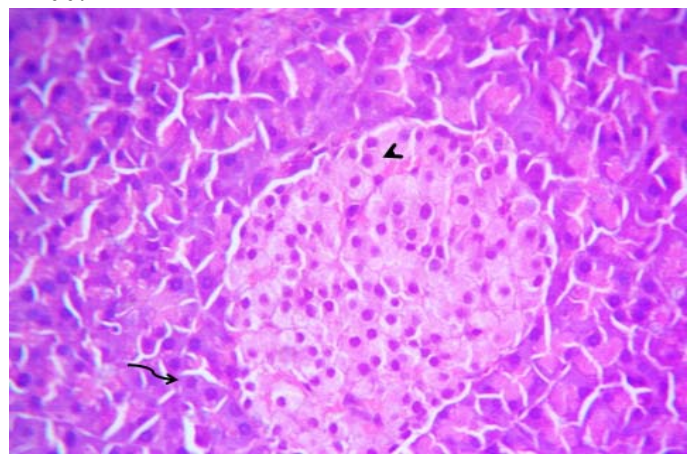

Photo. 6 (G6): Photomicrograph of pancreas showing normal pancreatic acini (curved arrow) and islets of Langerhans (arrow head). H\&E X400. 
As shown in Table (9) current study summarized that the best finding of histological examination was found in the pancreatic tissue of diabetic rats consumed biscuits fortified with $30 \%$ DF comparing with diabetic rats. This result is in agreement with results of glucose and insulin values in the present study. Also, this finding is in line with previous results for lipid profile as well as kidney and liver functions in the current study.

Table 9: Histological changes severity in the pancreatic tissue of diabetic rats consumed biscuits fortified with different levels of DF.

\begin{tabular}{|l|c|c|c|c|c|c|}
\hline Criteria & G1 & G2 & G3 & G4 & G5 & G6 \\
\hline Degenerative changes of Islets cells & - & +++ & +++ & ++ & + & - \\
\hline Islets cell death (apoptosis) & - & +++ & +++ & ++ & - & - \\
\hline Inflammatory cells infiltration & - & +++ & +++ & + & - & - \\
\hline Regenerative attempts & - & - & - & - & + & ++ \\
\hline $\begin{array}{l}\text {-: No alterations. } \\
\text { ++: Moderate (40-65\% alterations). }\end{array}$ \\
++ Mild (25-39\% alterations). \\
++: Severe (up to 65\% alterations).
\end{tabular}

\section{Conclusion:}

The present study revealed that inclusion DF in biscuits formula led to increase its nutritional functions. Organoleptic properties showed that biscuits fortified with DF up to $30 \%$ was acceptable. TP, TF and antioxidant activity in doum biscuits were higher than control biscuits in all substitution levels. Thus, addition of DF improved TP and TF levels in biscuits, hence led to higher antioxidant activity. Furthermore, doum biscuits have potent activity against hyperglycemia experimentally induced by alloxan due to its antioxidant properties. It can be advised to use doum biscuits as a protective and treatment of diabetes. Also, doum biscuits might be useful for people suffering from obesity and hyperlipidemia. 


\section{References:}

Abdel-moniem, M., Mustafa, H. N., Megahed, H. A., Agaibyi, M. H., Hegazy, G. A. and El-Dabaa, M. A. (2015). The ameliorative potential of Hyphaene thebaica on streptozotocin-induced diabetic nephropathy. Folia Morphol. 74(4): 447-457.

Abdel-Rahim, E. A., El-Beltagi, H. S. and Fayed, A. S. (2011). Comparative studies on the influences of Juniperus phoenicea and Hyphaene thebaica as hypoglycemic factors in diabetic rats. Adv. Food Sci. 33:128-132.

Abdelrashid, A. and Hassan, Z. M. R. (2005). Potential utilization and healthy effects of doum palm fruits in ice cream and sesame butter (Tehena). Alex. J. Food Sci. and Technol. 2(1):29-39.

Abdulazeez, M. A., Bashir, A., Adoyi, B. S., Mustapha, A. Z., Kurfi, B., Usman, A. Y. and Bala, R. K. (2019). Antioxidant, hypolipidemic and angiotensin converting enzyme inhibitory effects of flavonoid-rich fraction of Hyphaene thebaica (Doum Palm) fruits on fat-fed obese wistar rats. Asian J. Res. Biochem. 5(3): 1-11.

Aboshora, W., Jiahao, Y., Omar, K. A., Yinghao, L., Hassanin, H. A. M., Navicha, W. B. and Lianfu, Z. (2019). Preparation of doum fruit (Hyphaene thebaica) dietary fiber supplemented biscuits: influence on dough characteristics, biscuits quality, nutritional profile and antioxidant properties. J. Food Sci. and Technol. 56(3): 1328-1336.

Aboshora, W., Lianfu, Z., Dahir, M., Gasmalla, M. A. A., Musa, A., Omer, E. and Thapa, M. (2014). Physicochemical, nutritional and functional properties of the epicarp, flesh and pitted sample of doum fruit (Hyphaene thebaica). J. Food and Nutr. Res. 2(4): 180-186.

Aboshora, W., Lianfu, Z., Dahir, M., Qingran, M. ,Abubakr, M., Gasmalla, M. A. A. and Omar, K. A. (2016). Influence of doum (Hyphaene thebaica L.) flour addition on dough mixing properties, bread quality and antioxidant potential. J. Food Sci. Technol. 53(1):591-600.

Abou -Elalla, F. M. (2009). Antioxidant and anticancer activities of doum fruit extract (Hyphaene thebaica). Af. J. Pure. and Appl. Chem. 3(10): 197-201.

Abubakar, S., Etim, V. A., Usman, A. B., Isyaku, A. and Sabo, B. B. (2017). Nutraceutical Potential of two wild edible fruits growing in Sub-Sahara region of Nigeria. Am. J. Environ. Sci. and Eng.1(2): 52-58.

Abul-Fadl, M. M., Ibrahium, M. I., Abdel-Maksoud, B. S. and Ghanem, S. M. (2016). Effect of low calories pan bread containing wheat bran and some vegetable flours on biological properties of diabetic rats. Middle East J. Appl. Sci. 6(2): 315-328. 
Agarawal, S. R. (1994). Current and future trends of biscuits in Industry in India. Indian Food Ind.13(4):32-37.

Alsuhaibani, A. M. A. and Al-Kuraieef, A. N. (2018). Effect of low-calorie pumpkin jams fortified with soybean on diabetic rats: Study of chemical and sensory properties. J. Food Quality. (2):1-7.

Aniess, W. I. M., Khalil, A. F. and Mosa, Z. M. (2015). Phenolic compounds and antioxidants capacity of sweet lupine derivatives-wheat flour mixtures and the effects on diabetic rats. IOSR J. Environ. Sci., Toxicol. and Food Technol. 9(5):61-69.

AOAC, (2012). Official Methods of Analysis. Association of Official Analytical Chemistry (A.O.A.C) International, $19^{\text {th }}$ ed., Gaithersburg, Maryland, USA.

Atito, E., Moustafa, M. F., Siddiqui, S. and El-Sayed, M. (2019). Antioxidant, anti- $\alpha$-amylase and antimicrobial activities of doum (Hyphaene thebaica) and argun (Medemia argun) fruit parts. Int. J. Pharmacol. 15 (8): 953-961.

Bayad, A. E. (2016). Influences of doum fruit Hyphaene thebaica extract on the reproductive parameters, blood picture, lipid profile and hepato-renal functions in rats. Merit Res. J. Med. and Med. Sci. 4:384-391.

Bennet, C. (2004). Distribution of carbohydrate, protein, fat metabolism for diabetes. J. Diabet. Assoc. India. 4: 256-259.

Brand-Willians, W., Cuvelier, M. E. and Berset, C. (1995). Use of a free radical method to evaluate antioxidant activity. Food Sci. and Technol. 28(1): 25-30.

Buko, V., Lukivskaya, O., Nikitin, V., Tarasov, Y., Zavodink, L., Borodassky, A., Shatein, B. G., Janz, B. and Gundermann, K. J. (1996). Hepatic and pancreatic effects of polyenoylphatidylcholine in rats with alloxan - induced diabetes. Cell Biochem. Funct. 14 (2): 131 - 137.

Burstein, M., Scholnick, H. R. and Morfin, R. (1970). Rapid method for isolation of lipoprotein from human serum by precipitation with polyanions. J. Lipid Res. 11(6): 385- 395.

Chaney, S. G. (2006). Principles of Nutrition I: Macronutrients. In: Devlin, T.M. (ed.), Textbook of Biochemistry, with Clinical Correlation, $6^{\text {th }}$ ed. John Wiley and sons, New York, pp: 1071-1090.

Choudhury, M., Badwaik, L. S., Borah, P. K., Sit, N. and Deka, S. C. (2015). Influence of bamboo shoot powder fortification on physicochemical, textural and organoleptic characteristics of biscuits. J. Food Sci. Technol. 52:6742-674. 
El-Gendy, A., El-Mileegy, E., Ghyaty, H., Malek, A. and El-Hamid, M. (2008). The beneficial dietary hypotensive and hypolipidaemic effects of Hyphaene thebaica (Doum). Int. J. Altern. Med. 7(1): n. pag.

El-Hadidy, G. S. and El-Dreny, E. G. (2020). Effect of addition of doum fruits powder on chemical, rheological and nutritional properties of toast bread. Asian Food Sci. J. 16(2): 22-31.

Elhaj, N. A. and El-Bagir, N. M. (2016). Hypolipidemic effect of Hyphaene thebaica (Doum-palm) in induced hypercholestrolemic wistar albino rats. Int. J. Biochem and Biophys. 4(2): 11-15.

Famakin, O., Fatoyinbo, A., Ijarotimi, O. S., Badejo, A. A. and Fagbemi, T. N. (2016). Assessment of nutritional quality, glycaemic index, antidiabetic and sensory properties of plantain (Musa paradisiaca)-based functional dough meals. J. Food Sci. and Technol. 53(11): 3865-3875.

Farag, M. A. and Paré P. W. (2013). Phytochemical analysis and antiinflammatory potential of Hyphaene thebaica L. fruit. J. Food Sci.78:C1503-C1508.

Fletcher, R. (1997). Listing of useful plants of the world. Australian New Crops. Available

from: htp://www.newcrops.uq.edu.au/listing/hyphaenethebaica.

Fossati, P. and L. Prencipe (1982). Serum triglycerides determined colorimetrically with an enzyme that produces hydrogen peroxide. Clin. Chem. 28(10): 2077-2080.

Friedewald, W. T., Levy, K. T. and Fredrickson, D. S. (1972). Estimation of the concentration of low density lipoprotein cholesterol in plasma without use of the preparative ultracentrifuge. Clin. Chem. 226: 499-504.

Gharb, L. A. and Fadhel, L. Z. (2018). Antioxidant activity of two different extracts from doum (Hyphaene thebaica) fruits. IOSR J. Pharm. and Biolog. Sci. 13(4): 30-33.

Helal, E., Abou-Aouf, N., Khattab, S., Meselhy, A. and Abu-Amara, T. (2014). The effects of Ambrosia maritime, L. (Damsissa) on some biochemical and histological parameters of diabetic albino rats. Egypt. J. Hosp. Med. 57(1): 612-629.

Hsu, B., Coupar, I. M. and Ken, N. (2006). Antioxidant activity of hot water extract from the fruit of the Doum palm, Hyphaene thebaica. Food Chem. 98:317-328.

IBM SPSS Statistics. (2017). IBM SPSS Statistics for Windows, Version 25.0. IBM Corp., Armonk, New York. 
IDF Diabetes Atlas. (2019). International Diabetes Federation. $9^{\text {th }}$ ed. Brussels. pp. 34-68.

Kefale, B. and Yetenayet, B. (2020). Evaluation of bread prepared from composite flour of sweet lupine and bread wheat variety. J. Food Sci. Nutr. 6(1): 007-010.

Klein, B. and Kaufman, J. H. (1967). Automated alkaline phosphatase determination: III. Evaluation of Phenolphthalein Monophosphate. Clin. Chem. 13(4): 290-298.

Larson, K. (1972). Creatinine assay by a reaction principle. Clin. Chim. Acta. 41: 209-217.

Mohamed, A. A., Khalil, A. A. and El-Beltagi, H. E. S. (2010). Antioxidant and antimicrobial properties of kaff maryam Anastatica hierochuntica and doum palm Hyphaene thebaica. Grasas y Aceites. 61(1):67-75.

Mohamed, R. S., Marrez, D. A., Salem, S. H., Zaghloul, A. H., Ashoush, I. S., Farrag, A. R. and Abdel-salam, A. M. (2019). Hypoglycemic, hypolipidemic and antioxidant effects of green sprouts juice and functional dairy micronutrients against streptozotocin-induced oxidative stress and diabetes in rats. Heliyon 5:n. pag.

Mohammed, G. M and Zidan, N. S. (2018). Comparison between the chemical and antioxidant content of the Egyptian and Saudi doum fruit. Int. J. Pharm. Res. Allied Sci. 7(1):87-92.

Mohammed, M. M., Owis, A. I., Rabehc, M. A. and Hetta, M. H. (2019). Evaluation of anti-breast cancer activity of some edible plants cultivated in Egypt. Biosci. Res. 16(3): 3105-3109.

Manohar, S. R. and Rao P. H. (1999). Effect of emulsifier's fat level and type on the rhological characteristics of biscuit dough and quality of biscuits. J. Sci. Food and Agric., 79: 1223- 1231.

Patton, C. J. and Crouch, S. R. (1977). Spectrophotometric and kinetics investigation of the Berthelot reaction for the determination of ammonia. Anal. Chem. 49(3): 464-469.

Reeves, R., Nielsen, G. F. H. and Fahey, G. C. (1993). AIN-93 purified diets for laboratory rodents. J. Nutr. 123:1939.

Reitman, S. and Frankel, S. (1957). A calorimetric method for determination of serum AST. Am. J. Clin. Path.18:26.

Richmond, N. (1973). Preparation and properties of a cholesterol oxidase from Nacardia sp. enzymatic assay of total cholesterol in serum. Clin. Chem. 19 (12): 1350-1356. 
Saleh, A. M., Salama, A., Bedeir, S. H. and Abd-Elazim, E. (2012). Effect of partial substitution of wheat flour with either defatted soybean or chickpea flours at different ratios on rheological and physical properties of dough, and quality characteristics of biscuits. J. Appl. Sci. Res. 8 (12): 58065817.

Salib, J. Y., Michael, H. N. and Eskander, E. F. (2013). Anti-diabetic properties of flavonoid compounds isolated from Hyphaene thebaica epicarp on alloxan induced diabetic rats. Pharm. Res. 5(1): 22-29.

Seleem, H. A. (2015). Effect of blending doum (Hyphaene thebaica) powder with wheat flour on the nutritional value and quality of cake. Food and Nutr. Sci. 6: 622-632.

Shehata, S. M. and Abd El-Ghffar, E. A. (2017). Hepatoprotective activity of Hyphaene thebaica extract against mercuric chloride-induced hepatotoxicity in adult male albino rats. Progress in Nutr. 19(1-S):142149.

Siddeeg, A., Salih, Z. A. 1., Al-Farga, A., Ata-Elfadeel, E. M. A. and Ali, A. O. (2019). Physiochemical, nutritional and functional properties of doum (Hyphene thebaica) powder and its application in some processed food products. J. Nutr. Food Sci. Forecast. 2(1): 1009.

Singleton, V. L., Orthofer, R. and Lamuela-Raventos, R. M. (1999). Analysis of total phenols and other oxidation substrates and antioxidants by means of Folin Ciocalteu reagent. Method. Enzymol. 299: 152-178.

Suvarna, K. S, Christopher, L. and Bancroft, J. D. (2013). Bancroft's Theory and Practice of Histological Techniques. $7^{\text {th }}$ Edition.

Taha, G. A., Abdel-Farid, I. B., Elgebaly, H. A., Mahalel, U. A., Sheded, M. G., Bin-Jumah, M. and Mahmoud, A. M. (2020). Metabolomic profiling and antioxidant, anticancer and antimicrobial activities of Hyphaene thebaica. Processes. 8: 266.

Temple, R. C., Clark, P. M. and Hales, C. N. (1992). Measurement of insulin secretion in type 2 diabetes: problems and pitfalls. Diabet. Med. 9(6): 503512.

Tohamy, A. A., Abdalla, M. S., Ibrahim, A. K., Ahmed, K. A., Mahran, K. F. and Mohammed, R. S. (2013a). The Effect of Lupinus albus and Hyphaene thebaica on chromosomal aberrations and histopathological changes of liver and pancreas in streptozotocin-induced diabetic rats. Egypt. J. Hosp. Med. 53: 763-769.

Tohamy, A. A., Abdalla, M. S., Ibrahim, A. K., Mahran, K. F. and Mohammed, R. S. (2013b). The effect of Lupinus Albus (Termis) and Hyphaene Thebaica (Doum) on some biochemical parameters in streptozotocin-induced diabetic rats. Egypt. J. Hosp. Med. 53: 789-794. 
Trinder, P. (1969). Determination of glucose in blood using glucose oxidase with an alternative oxygen acceptor. Ann. Clin. Biochem. 6 (1): 24-27.

Tripathi, B. K. and Srivastava, A. K. (2006). Diabetes mellitus: complications and therapeutics. Med. Sci. Monit. 12(7):RA130-RA147.

WHO, (2006). Definition and diagnosis of diabetes mellitus and intermediate hyperglycaemia Report of a WHO/IDF Consultation. pp. 1-50.

Williamson, J. C., Glauser, T. A., Nevins, P. H., Schneider, D., Kruger, D. F., Urquhart, B. S., Whitfield, S. F. and Dubois, A. M. (2013). Current practice patterns and identified educational needs of health care providers in managing patients with type 2 diabetes. J. Clin. Diabetes. 31(1):3-9.

Zheng, H., Whitman, S. A., Wu, W., Wondrak, G. T., Wong, P. K., Fang, D. and Zhang, D. D. (2011). Therapeutic potential of Nrf2 activators in streptozotocin-induced diabetic nephropathy. Diabetes. 60: 3055-3066.

Zhishen, J., Mengcheng, T. and Jianming, W. (1999). The determination of flavonoid contents in mulberry and their scavenging effects on superoxide radicals. Food Chem. 64(4): 555-559.

\section{الملخص العربي}

تأثير تلعيم البسكويت بدقيق الدوم على سمات الجودة والقياسات البيوكيميائية

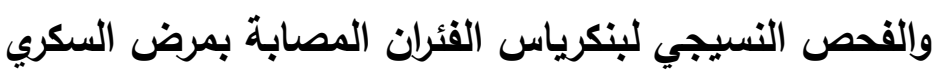

مع الاستخدام الواسع النطاق للأغذية الوظيفية، يبحث العالم عن منتجات غذائية صحية جديدة بنسب مناسبة من المكونات النشطة بيولوجياً متل الألياف والمركبات الفينولية والفلافونويدات. ويُعتبر الدوم مصدر غني بالألياف ومضادات الأكسدة. ويهدف هذا البحث إلى استخدام دقيق الدوم في

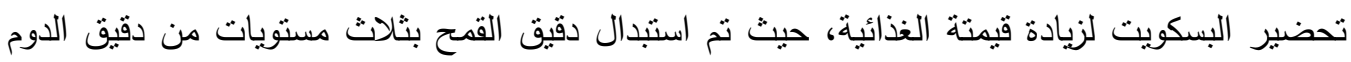

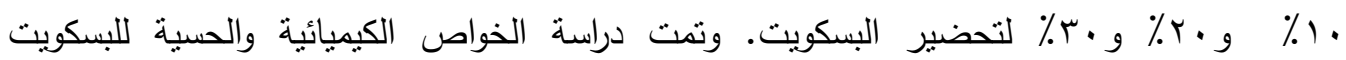
المحضر. كما تم تقييم تأثير تغذية الفئران المصابة بمرض السكري ببسكويت الدوم على الاختبارات

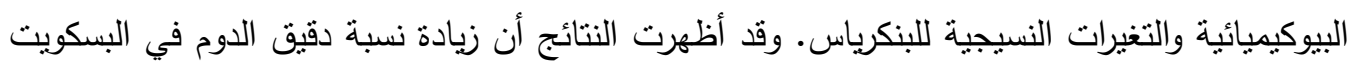

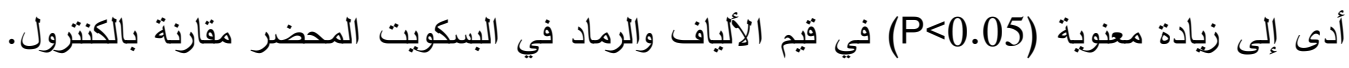

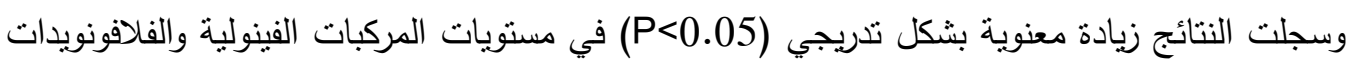


وكذللك النشاط المضاد للأكسدة بزيادة مستوى دقيق الدوم في البسكويت مقارنة بالكنترول. وقد أظهر

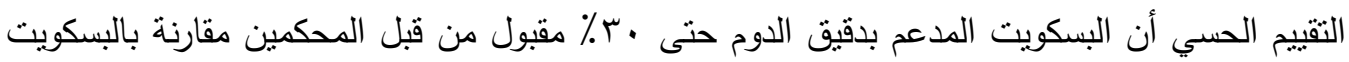
الكنترول. وقد لوحظ انخفاضاً معنوياً (P>0.05) في مستويات الجلوكوز في الدم والكوليسترول والدهون

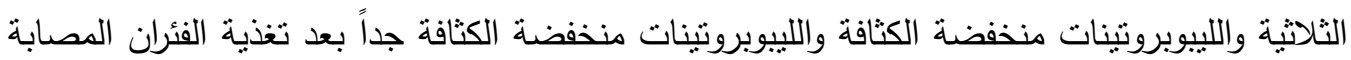

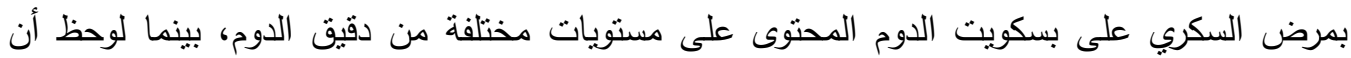
هناك زيادة معنوية (P<0.05) في مستويات الأنسولين والليبوبروتينات مرتفعة الكثافة مقارنة مع الفئران

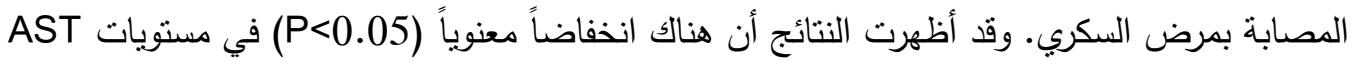

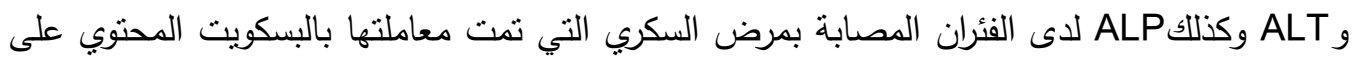

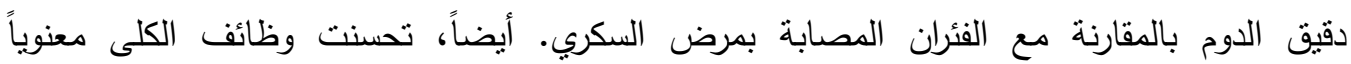
(الفئران المصابة بمرض السكري الني تغذت على بسكويت الدوم، حيث انخفضت قيم

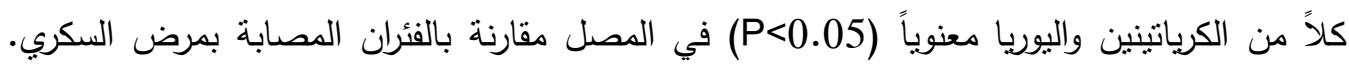

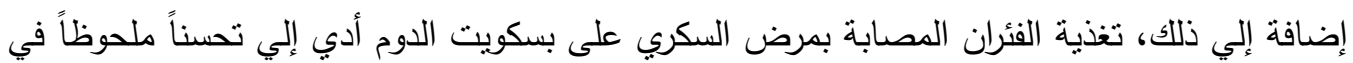
أنسجة البنكرياس وتتقق هذه النتائج مع النتائج التي تم الحصول عليها أعلاه. وأكدت النتائج أن أفضل تحسن لجميع القياسات وُجد في مجموعة الفئران المصابة بمرض السكري التي تم تغذيتها على بسكويت

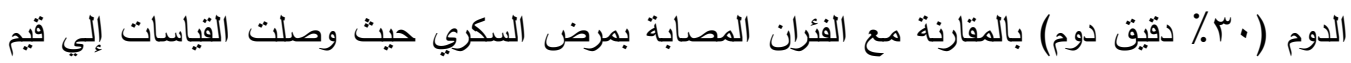

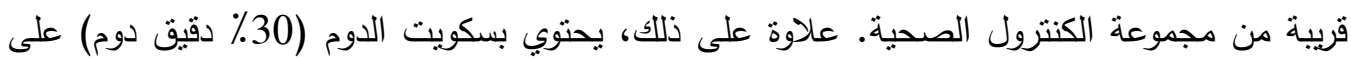

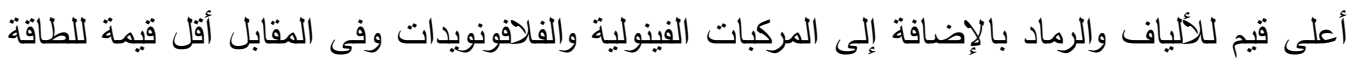
مقارنة بالبسكويت الكنترول. وبناءً على ذلك ، يمكن الاستتناج أن بسكويت الدوم الذي تم إنتاجه بتكلفة

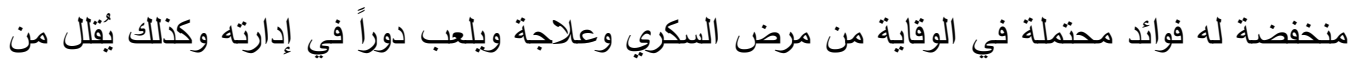

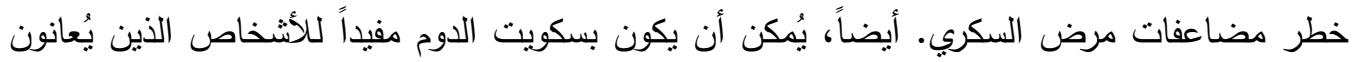

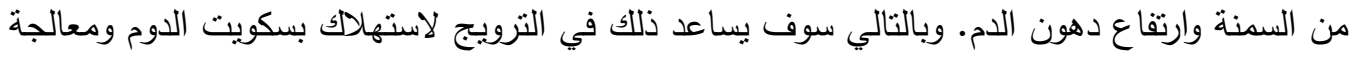
المشاكل المتعلقة بالتغذية في مصر ـ لذلك، توصي الدراسة الحالية بزيادة استهلالك المخبوزات المدعمة بدقيق الدوم وزيادة وعي المستهكين بفوائد استهلاك المنتجات الغذائية المصنعة من الدوم لأهميتها بادها

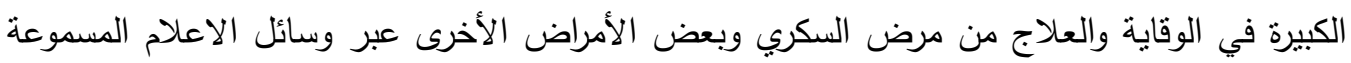
والمرئية والمراكز الصحية.

الكلمات المفتاحية: الدوم - البسكويت - التدعيم - النشاط المضاد للاكسدة - الالوكزان - التقييم الحسي - مرض السكري. 